\title{
Ovarian follicular populations and preovulatory enlargement in Booroola and control Merino ewes
}

\author{
M. A. Driancourt*, L. P. Cahill and B. M. Bindon $\ddagger$ \\ Animal Research Institute, Werribee, Victoria 3030 and $\ddagger$ CSIRO, Division of Animal Production, \\ Armidale, New South Wales 2350, Australia
}

\begin{abstract}
Summary. To investigate the factors contributing to the different ovulation rates observed in two strains of sheep (Booroola 5.2, Merino 1.2), in-vivo monitoring of follicular kinetics followed by histological examination of both ovaries was performed during the late luteal and follicular phases. Ewes of both strains were either ovariectomized at Day 13, or had the 3 largest follicles of each ovary ink-labelled at Day 13 and were ovariectomized at Day 15, or had the 3 largest follicles of each ovary inklabelled at Days 13 and 15 and were ovariectomized $16 \mathrm{~h}$ after the beginning of oestrus ( $N=6$ per time per strain). In another experiment, the age effects on the follicular populations of these two strains were also studied.

There were 2-4 times more primordial follicles and 1.5-2 times more preantral follicles in the ovaries of Booroola than in control Merino ewes, although the number of antral follicles was the same. The percentage of normal follicles in this population was higher in Merino than Booroola ovaries. In Booroola ewes, there was no correlation between the number of antral follicles per ovary and the ovulation rate at the previous cycle $(r=0 \cdot 22)$. This suggests that follicle numbers do not play a key role in the high ovulation rate of the Booroola strain. The number of follicles initiating growth from the primordial pool, the number of growing follicles disappearing at the preantral stage, the pattern of antrum development, granulosa cell multiplication and appearance of atresia differed between strains.

The reasons for the high ovulation rate of the Booroola strain became clear when preovulatory enlargement was followed by ink labelling. An extended period of time during which recruitment of ovulatory follicles takes place, together with a low incidence of selection and the ability of the follicles to wait for ovulation are the features involved in this high ovulation rate.
\end{abstract}

\section{Introduction}

Four variables have been shown to modulate ovulation rate in sheep: body weight (Lindsay, Knight, Smith \& Oldham, 1975), season (Wheeler \& Land, 1977), age (McKenzie \& Terrill, 1937; Lindsay et al., 1975) and breed (Scaramuzzi \& Radford, 1983). In a given breed, the age-induced changes in ovulation rate have been described: from a minimum in young ewes, 8-18 months old, ovulation rate rises to a maximum at 6-8 years of age, followed by a slight decrease with further ageing (McKenzie \& Terrill, 1937). Whether this pattern of changing ovulation rate is reflected in the different components of the follicular population is unknown.

Our understanding of the mechanisms responsible of the high ovulation rate of the prolific breeds (Romanov, Booroola, Finnish-Landrace and D'Man) is also scarce. Ovulation rate is the result of a complex interaction between endogenous gonadotrophins and ovarian sensitivity to 
gonadotrophins (Land \& Falconer, 1969), possibly modulated by some intraovarian factors. Evidence for higher circulating gonadotrophin concentrations during the follicular phase has been obtained for FSH in two of the prolific breeds (Booroola: Bindon et al., 1984; D'Man: LahlouKassi, Schams \& Glatzel, 1984) but not in the others (Romanov: Bindon, Blanc, Pelletier, Terqui \& Thimonier, 1979; Cahill et al., 1981; Finnish-Landrace: Webb \& England, 1982). Increased ovarian sensitivity to gonadotrophins is indicated by the greater response of prolific breeds to exogenous gonadotrophins (Booroola: Bindon \& Piper, 1982). The increased ovarian sensitivity might be mediated through higher follicle numbers, as observed in Romanov ewes (Cahill, Mariana \& Mauléon, 1979), or through a greater sensitivity of individual follicles to gonadotrophins. In this study, follicular populations, some morphological indices of follicular sensitivity to gonadotrophins and the pattern of preovulatory enlargement have been compared in two strains of Merino sheep from several age groups.

\section{Materials and Methods}

Animals and experimental design

Experiment I. Booroola $(\mathrm{N}=20)$ and control Merino $(\mathrm{N}=20)$ ewes, matched for age ( $3-4$ years old) and body condition, were obtained from CSIRO, Armidale. According to the number of corpora lutea found at repeated laparoscopies before the experiment, all 20 of the Booroola ewes were carrying at least one copy of the putative Booroola gene (Davis, Montgomery, Allison \& Kelly, 1982): 12 of them were probably heterozygous for the gene (ovulation rate 3-4) and 8 homozygous (ovulation rate $\geqslant 5$ ). In the control Merinos in Armidale, the occurrence of twin ovulations did not exceed $15 \%$.

During the mid-breeding season (May), at the Animal Research Institute, Werribee, oestrous cycles in all the ewes were synchronized by progestagen-impregnated sponges (Repromap: Upjohn) inserted for 14 days. Intensive inspection for oestrus (every $3 \mathrm{~h}$ for $48 \mathrm{~h}$ ) was started $36 \mathrm{~h}$ after sponge removal to detect the start of oestrus (Day 0 ).

Then, within each strain, ewes were randomized in three groups according to age and their previous records of ovulation rate. Ewes of Group I (6 per strain) were ovariectomized at Day 13 after careful measurement of the diameter of the 3 largest follicles of each ovary as previously described (Driancourt \& Cahill, 1984). Ewes of Group II (6 per strain) underwent a laparotomy at Day 13, during which the 3 largest follicles of each ovary were measured and ink-labelled by dots of ink into the stroma surrounding the follicle (Dufour, Whitmore, Ginther \& Casida, 1972; Driancourt \& Cahill, 1984). At Day 15, these ewes were ovariectomized after measurement of the previously labelled follicles and of the 3 largest follicles of each ovary. Ewes of Group III (8 per strain) were laparotomized at Days 13 and 15 for measurement and ink labelling of the 3 largest follicles and of previously labelled follicles. At $16 \mathrm{~h}$ after the beginning of oestrus, the ewes were ovariectomized after another check of the size and appearance of large labelled and unlabelled follicles. From Day 12 until ovariectomy, blood samples were taken twice daily to measure progesterone levels and follow luteolysis.

Experiment II. Six Booroola and 6 control Merino ewes aged 2 or 8 years ( 3 ewes per strain per age) were ovariectomized during the luteal phase and one ovary was studied histologically.

\section{Histological techniques and follicular populations}

After ovariectomy, the ovaries were fixed in Bouin-Hollande's solution, serially sectioned at a thickness of $7 \mu \mathrm{m}$ and the sections were stained with Feulgen's stain.

Follicles were counted and measured according to the techniques previously described (Cahill et al., 1979; Driancourt \& Mariana, 1982). Briefly, the follicle population was divided into primordial follicles with $<3$ layers of granulosa cells and $<60 \mu \mathrm{m}$ in diameter and growing follicles $>60$ $\mu \mathrm{m}$ in diameter. The number of primordial follicles was estimated (Exp. II) from counting the 
number of follicles in every 120 th section using the nucleolus of the oocyte as a marker and Abercrombie's (1946) correction factor. The number of preantral follicles was counted, using the nucleolus of the oocyte as a marker, in one ovary of 6 ewes of each strain sampled at the preovulatory stage (Exp. I) and in all the ovaries of Exp. II. A follicle was said to be antral if there was a clear cavity exceeding $1000 \mu \mathrm{m}^{2}$ in the granulosa cells. The number of antral follicles was counted in both ovaries of the ewes of Exp. I for which 1 section out of 6 was mounted and in the ovaries of ewes in Exp. II, which were fully mounted, using the oocyte (Exp. I) or the nucleolus of the oocyte (Exp. II) as a marker.

The area of all growing follicles was measured in $\mu \mathrm{m}^{2}$ and then converted to $\mathrm{mm}$, assuming that the follicle was circular. Arbitrary size classes were built to compare the events of follicular development in these two strains. However, the general lack of synchronism in the different steps of follicular development (see 'Results') together with the markedly smaller size of preovulatory follicles in Booroola compared to control Merino ewes (Baird, Ralph, Seamark, Amato \& Bindon, 1982), precluded any strict comparisons between follicular numbers in a given size class.

To be able to compare in-vivo and histological measures, two estimates were needed; firstly, the amount of follicular shrinkage induced by histological processing, and, secondly, the underestimation of follicular size introduced by using the oocyte as a marker. The size of 50 follicles $\geqslant 2$ $\mathrm{mm}$ measured in vivo was compared with their size on the largest section (i.e. the section halfway between the appearance and disappearance of the follicle in the successive sections, assuming the follicle is spherical), measured with an overhead projection microscope, planimeter and computer. For follicles of $2 \mathrm{~mm}(n=23), 3 \mathrm{~mm}(n=17)$ and $4 \mathrm{~mm}(n=10)$, the 'histological' sizes were $3080000 \mu \mathrm{m}^{2}, 4150000 \mu \mathrm{m}^{2}$ and $5947000 \mu \mathrm{m}^{2}$ respectively compared with actual sizes of $3140000 \mu \mathrm{m}^{2}, 7065000 \mu \mathrm{m}^{2}$ and $12560000 \mu \mathrm{m}^{2}$ respectively, Hence shrinkage due to processing was slight in follicles $\leqslant 2 \mathrm{~mm}$ in diameter but histological size was 58 and $47 \%$ of the actual size for the 3- and 4-mm follicles. Comparison of the shrinkage in Booroola Merinos and control Merinos for $2 \mathrm{~mm}$ follicles did not show any significant difference between strains. The same 50 follicles $\geqslant 2$ $\mathrm{mm}$ were used to estimate the error linked to the use of the oocyte as a marker of the section where size is measured. Comparison of the size of the section in which the oocyte was found and of the largest section (i.e. the section halfway between the appearance and disappearance of the follicle) showed that the mean underestimation of follicular size using the oocyte as a marker was $16 \%$ (range $0-42 \%$ ). Because of this limited underestimation and the time taken to find the largest section, all follicles were measured in the section where the oocyte was found; an overhead projection microscope, planimeter and computer were used.

\section{Follicular kinetics}

The number of cells undergoing mitosis and the number of granulosa cells were measured in 6 control Merino and 6 Booroola ewes sampled at the preovulatory stage. For each ewe, 14 preantral ( 7 follicles $<0.1 \mathrm{~mm}$ and 7 of $0.1-0.2 \mathrm{~mm}$ in diameter) and 5 normal antral follicles for each of the previously defined size classes were studied. In preantral follicles, the number of granulosa cells was counted in the section where the nucleolus of the oocyte was visible. The number of mitotic figures in this section and the following one was also counted. In antral follicles, the number of granulosa cells was calculated from the mean cellular density of each follicle (measured in 5-10 areas according to follicular size with a circular graticule of known area) and the area occupied by granulosa cells (obtained as the difference between the total follicular area bounded by the basal membrane and the antrum area, or, for very large follicles, from the antrum area and the thickness of the granulosa layer at 12 different places according to Gougeon (1981)). The total number of cells per follicle was obtained as described by Pedersen (1970) and Gougeon (1981). Mitotic figures were counted only in one section studied. The mitotic index was defined as the ratio between the number of mitotic figures observed and the total number of cells in the section studied. 
To study the duration of follicular growth, the total number of cells for a follicle of a given size was calculated as described by Pedersen (1970). Then doubling times and transit times were computed according to Hoffman (1949) and Pedersen (1970), using $1.38 \mathrm{~h}$ as the duration of mitosis (Cahill \& Mauléon, 1980). Estimates of the number of follicles entering a given size class daily were obtained according to Turnbull, Braden \& Mattner (1977) by dividing the number of follicles found in that class by the time spent in that class.

\section{Definitions}

Preovulatory follicles. A follicle was defined as preovulatory if it was healthy, larger than $3 \mathrm{~mm}$ or $5 \mathrm{~mm}$ in diameter for Booroola and control Merino ewes respectively and had dispersed granulosa cells surrounding the oocyte. However, due to the difference in timing of the preovulatory events in Booroola and control Merinos (Bindon, Piper \& Evans, 1982), dispersion of the cumulus cells was never observed in control Merinos $16 \mathrm{~h}$ after the beginning of oestrus. The large healthy follicles of this strain are therefore referred to as putative preovulatory follicles.

Atresia. Follicles were classified as normal or atretic. An atretic follicle was defined as a follicle with $>5$ pycnotic bodies at the edge or amongst the granulosa cells of the section studied. Included in this class of atretic follicles were follicles with widespread disintegration of the granulosa cells but still containing an oocyte. Follicles in very late atresia, in which no oocyte could be found, were not considered in this study.

Recruitable follicles. Observations in vivo have shown that, in Corriedale (Driancourt \& Cahill, 1984) and in Merino (see 'Results') sheep, the future preovulatory follicles are of any size $>2 \mathrm{~mm}$ around the time of luteolysis. However, since most events of follicular growth proceed at a smaller size in Booroola than in Merino sheep, the lowest size at which follicles can be recruited was $<2$ $\mathrm{mm}$ and could not be accurately defined in vivo in Booroola ewes. Recruitable follicles in both strains were therefore defined as the follicles larger than the mean of all the largest and second largest healthy follicles (preovulatory excepted) in the ovaries of each strain taken at the preovulatory stage, i.e. 1.35 in Booroola and $1.5 \mathrm{~mm}$ in control ewes. The rationale for this definition is as follows. Firstly, it is at the time of ovulation that the size of the largest healthy nonpreovulatory follicle is minimal, due to the decreased FSH levels and to the presence of a dominant follicle (ewes: Driancourt \& Cahill, 1984; mares: Driancourt, Mariana \& Palmer, 1982a; women: Gougeon \& Lefèvre, 1983). That these follicles are recruitable is indicated by the observation that when a preovulatory or recently ovulated follicle is cauterized, the time lag to the next ovulation is of a duration similar to a normal follicular phase (ewes: Smeaton \& Robertson, 1971; women: Nilsson, Wikland \& Hamberger, 1982). Secondly, in Merinos, the follicular size after correction for histological shrinkage and use of the oocyte as a marker fits well with the size observed in vivo (i.e. $2 \mathrm{~mm}$ ).

\section{Assays}

Plasma progesterone concentration was measured by radioimmunoassay as described by Hossain, Lee, Clarke \& O'Shea (1979). Assay sensitivity was $0.05 \mathrm{ng} / \mathrm{ml}$. The only significant crossreactions were with $11 \alpha$-hydroxyprogesterone $(27 \%)$ and corticosterone $(5 \cdot 8 \%)$. Plasma pools from one wether $(0.03 \pm 0.01 \mathrm{ng} / \mathrm{ml})$ and 2 ewes $(2.4 \pm 0.11$ and $4.2 \pm 0.19 \mathrm{ng} / \mathrm{ml})$ were used to establish the within-assay variation $(15.9 \pm 1.3 \%)$ and the between-assay variation $(17.6 \pm 4.3 \%)$.

\section{Statistical methods}

Means were compared by $t$ tests or analysis of variance and distributions by 2 I tests (Sokal \& Rohlf, 1969). 


\section{Results}

The ovulation rate found in Exp. I, calculated from the number of corpora lutea of the previous cycle, was $5.2 \pm 1.5$ (s.d.) for Booroola and $1.2 \pm 0.4$ for control Merino ewes, which accurately represents the normal ovulation rate of each strain. Two control Merinos from Group III developed persistent corpora lutea and 2 Booroola ewes from the same group exhibited incomplete luteolysis ( $2 \mathrm{CL}$ out of 9 and 2 out of 6 were maintained). All these ewes were therefore excluded from the study. In the remainder of the Group III ewes (i.e. 6 ewes per strain), the number of preovulatory follicles was similar to the number of corpora lutea from the previous cycle (the difference never exceeded one), suggesting that the experimental procedure did not upset the physiological mechanisms contributing to preovulatory development.

\section{Morphological events of follicular growth (Exp. I)}

Antrum formation and development. The size at which a detectable antrum $\left(>1000 \mu \mathrm{m}^{2}\right)$ was first noticeable was highly variable both between animals and between follicles. Follicles with or devoid of an antrum were found when their area varied between 20000 and $120000 \mu \mathrm{m}^{2}$. To study the pattern of antrum formation in each strain, this size range was divided into 6 smaller size classes for which the proportion of follicles having an antrum was computed for 6 ewes of each strain. Comparison between strains of the percentage of antral follicles in the 6 successive classes did not show any difference in the size at which the antrum appeared (Text-fig. 1). Further antrum development was compared by calculating for each of the same ewes the linear regressions linking antrum area and follicle area. A significant difference between strains was found in the slopes of these regressions (Booroola, $1.75 \pm 0.07$ (s.d.); control Merino, $1.48 \pm 0.04 ; P<0.01$ ) suggesting that, at a given size, the follicles of Booroola ewes will have a larger antrum and a smaller surface occupied by granulosa cells.

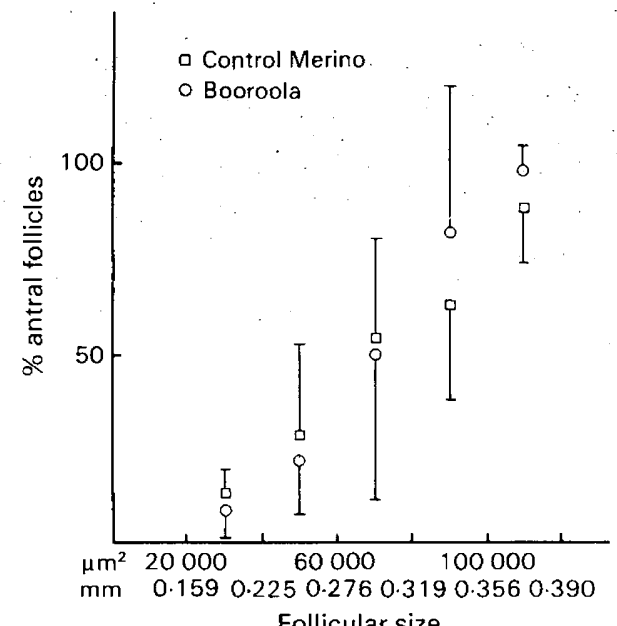

Text-fig. 1. Pattern of antrum formation in control Merino and Booroola sheep.

Granulosa cell multiplication. The changes of the mitotic index of the granulosa cells with follicular size are presented in Text-fig. 2 for each of the strains as the mean value of the 6 ewes of each strain. While the overall pattern was similar between strains, the curve was shifted to the right in control Merinos, i.e. the mitotic index of preantral follicles was similar in both strains, but it increased earlier in Booroola ewes as shown by the significantly higher value in Booroolas for follicles $0.27-0.35 \mathrm{~mm}(P<0.01), 0.35-0.56 \mathrm{~mm}(P<0.05)$ and $0.56-0.80 \mathrm{~mm}(P<0.05)$. The 


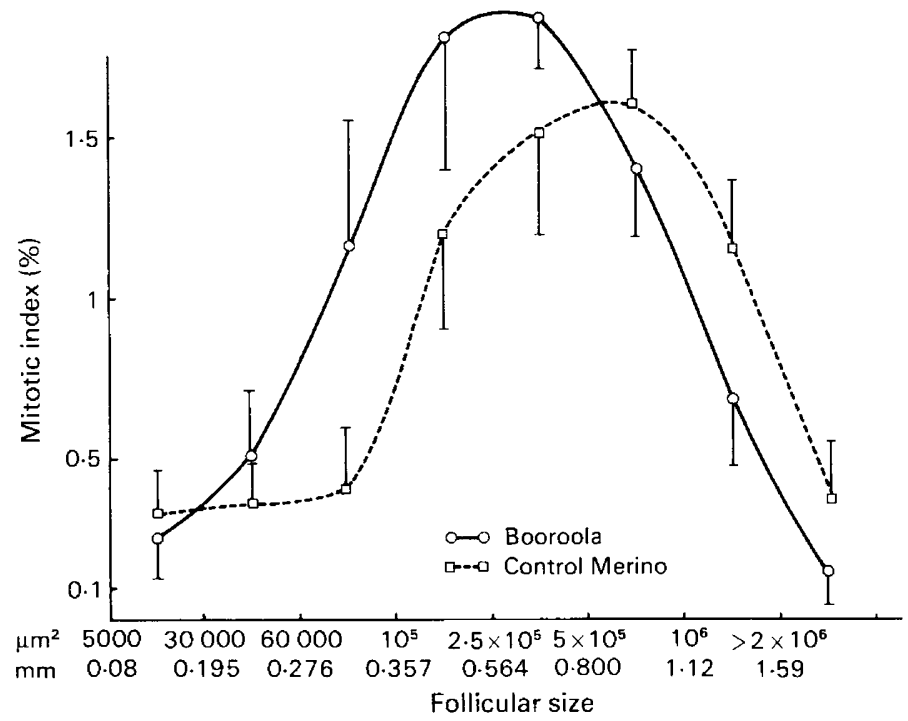

Text-fig. 2. Mean mitotic index per size class in the granulosa cells of Booroola and control Merino sheep.

mitotic index declined earlier in Booroola than in control Merinos, and, for follicles 1.12-1.59 and $1.59-2.52 \mathrm{~mm}$, the mitotic index of the Merinos was significantly higher than that of the Booroolas $(P<0.05)$.

Transit times through each of the size classes are presented in Table 1 for each strain. Duration of transit through the preantral phase was similar in the 2 strains (54 days and 49 days in Booroola and Merino ewes, respectively). Estimates of 2.12 and 1.34 follicles starting to grow per day in Booroola and control Merino ewes were obtained by dividing the number of preantral follicles of each strain by transit time. For antral follicles, the mean time between antrum formation and a diameter of $1.6 \mathrm{~mm}$ was 19 days for Booroola and 29 days for control Merinos. Estimates of 1.1 and $1 \cdot 1$ follicles entering the antral phase daily in Booroola and Merino ewes were calculated from the time spent in the first two antral classes where there is very little atresia and the mean number of follicles in these classes.

Table 1. Doubling and transit times through the successive size classes in Booroola and control Merino ewes

\begin{tabular}{|c|c|c|c|c|c|c|c|}
\hline & \multicolumn{7}{|c|}{ Size $(\mathrm{mm})$} \\
\hline & $\begin{array}{l}0 \cdot 08- \\
0 \cdot 195\end{array}$ & $\begin{array}{c}0.196- \\
0.276\end{array}$ & $\begin{array}{c}0.277- \\
0.357\end{array}$ & $\begin{array}{c}0.358- \\
0.564\end{array}$ & $\begin{array}{c}0.565- \\
0.800\end{array}$ & $\begin{array}{c}0.801- \\
1 \cdot 12\end{array}$ & $\begin{array}{c}1.13 \\
1.59\end{array}$ \\
\hline \multicolumn{8}{|l|}{ Booroola } \\
\hline Mean mitotic index $(\%)$ & $0 \cdot 26$ & 0.51 & $1 \cdot 16$ & $1 \cdot 80$ & 1.87 & 1.40 & 0.79 \\
\hline Doubling time (h) & 371 & 189 & 83 & 54 & 51 & 69 & 122 \\
\hline Transit time (h) & 1057 & 234 & 99 & 101 & 79 & 68 & 120 \\
\hline \multicolumn{8}{|l|}{ Control Merino } \\
\hline Mean mitotic index $(\%)$ & $0 \cdot 33$ & $0 \cdot 34$ & 0.40 & $1 \cdot 20$ & 1.50 & 1.59 & $1 \cdot 15$ \\
\hline Doubling time $(\mathrm{h})$ & 290 & 282 & 240 & 80 & 64 & 60 & 84 \\
\hline Transit time (h) & 826 & 355 & 285 & 163 & 91 & 65 & 84 \\
\hline
\end{tabular}

Appearance of atresia. From all the ovaries of each strain, the size distribution of the early atretic follicles was calculated (Table 2 ). The distribution differed significantly $(P<0.01)$, suggesting that atresia appears in smaller follicles in Booroola ewes. 
Table 2. Distribution $(\%)$ of the early atretic follicles in size classes in Booroola and control Merino ewes

\begin{tabular}{lcrccr}
\hline & \multicolumn{5}{c}{ Size (mm) } \\
\cline { 2 - 6 } & $<0.56$ & $0.56-$ & $0.81-$ & $1.13-$ & $>1.59$ \\
\hline Booroola & 9.6 & 22.5 & 30.6 & 29.0 & 8.1 \\
Merino & 4.7 & 4.7 & 19.1 & 57.1 & 16.7 \\
\hline
\end{tabular}

Follicular populations in the two strains (Exp. I)

In the 6 ewes of each strain in which the population of preantral follicles was studied, ovaries of Booroola ewes contained more preantral follicles $(115.5 \pm 38.7$ (s.d.) than did controls $(66.5 \pm$ $12.9 ; P<0.05)$. The variability of their number was also higher in Booroolas $(P<0.05)$ (Text-fig. 3a). In contrast, no significant difference in the total number (normal and atretic) of antral follicles was found between strains (Text-fig. 3b), with Booroola and control Merino ewes having mean populations of $43.3 \pm 16.6$ (s.d.) and $50.7 \pm 18.4$ follicles respectively. Despite this similarity, two features of this antral population differed between strains. Firstly, the percentage of normal follicles in this population was significantly higher in Merino than in Booroola ewes ( $73.5 \pm 9 \cdot 1$ (s.d.) compared with $61 \cdot 1 \pm 8 \cdot 3 ; P<0 \cdot 05$ ). Secondly, the distribution of normal follicles in size classes differed significantly between strains $(P<0.05)$, with the control Merinos showing an accumulation of follicles in the small antrum classes (Text-fig. 4).
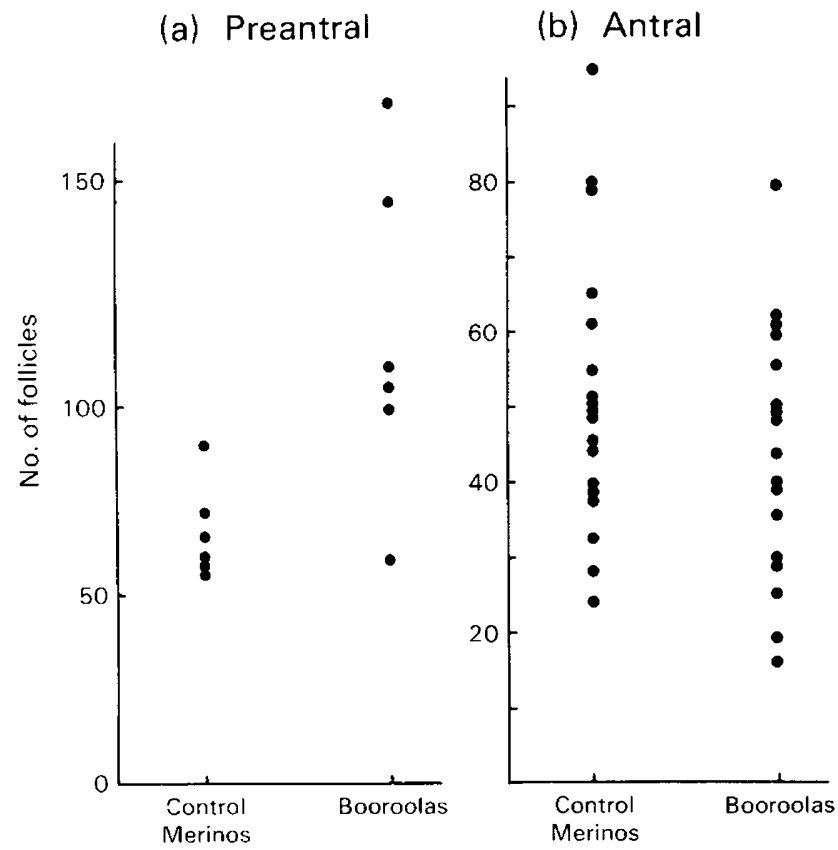

Text-fig. 3. Numbers of (a) preantral and (b) antral follicles per ovary in Booroola and control Merino ewes.

For each strain, the relationship between follicle numbers and mitotic index was investigated by calculating for each of the 6 antral classes the correlation coefficients between the mitotic index and the number of normal follicles (Table 3). There was no significant correlation in any size class 


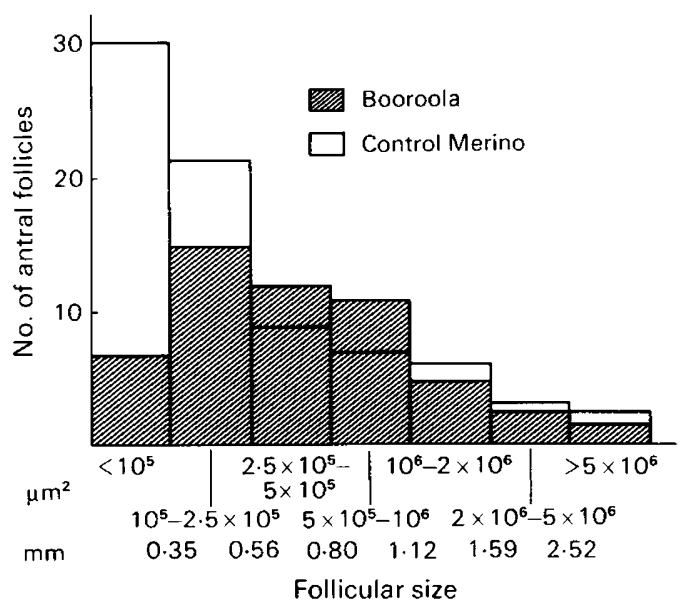

Text-fig. 4. Mean distribution in size classes of the normal antral follicles in Booroola and control Merino ewes.

Table 3. Correlation coefficients linking follicle numbers $(\mathrm{N})$ and mitotic index (MI) in a given class, and also mitotic indices in successive size classes in Booroola and control Merino ewes

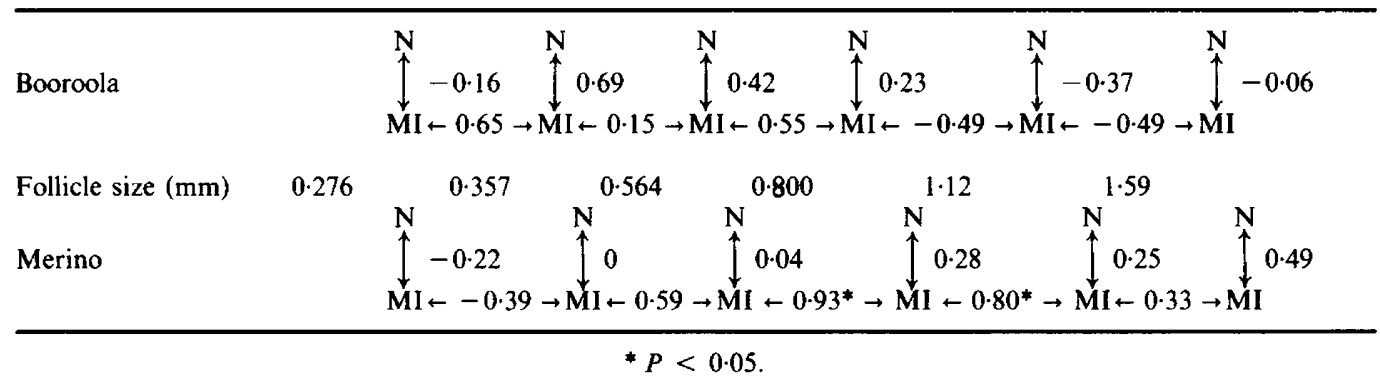

for either strain. In addition, there was generally no correlation between the mitotic indices in successive size classes.

\section{Within-breed variation in follicular population (Exp. I)}

The number of corpora lutea of the previous cycle was recorded for all the ewes at the time of ovariectomy. In Booroola ewes, there was no correlation between the number of antral follicles per ovary and the ovulation rate at the preceding cycle $(r=0.22)$ (Text-fig. 5). In contrast, the 5 control Merino ewes that had 2 ovulations in the previous cycle had significantly more follicles in the antral population than did the 13 with only a single ovulation $(71 \cdot 2 \pm 17.5$ (s.d.) compared with $43.4 \pm$ $11.2 ; P<0.05)$. These twin-ovulating Merinos had more follicles in all the size classes but the shapes of the distributions were similar in single and twin-ovulating ewes.

\section{Pattern of follicular development indicated by ink labelling (Exp. I)}

In Groups II and III, of the follicles labelled at Day 13, neither the number that grew between Days 13 and 15 nor the number that regressed between Days 13 and 15 differed between strains (Table 4). Similarly, the number of follicles emerging between Days 13 and 15 to become among the 3 largest of each ovary did not differ. In contrast, the numbers of follicles labelled at Day 15 and growing between Days 15 and 17, and of those not labelled at Day 15 but appearing as preovulatory follicles at Day 17, were significantly higher $(P<0.01)$ in Booroola than in control Merino ewes (Table 4). 


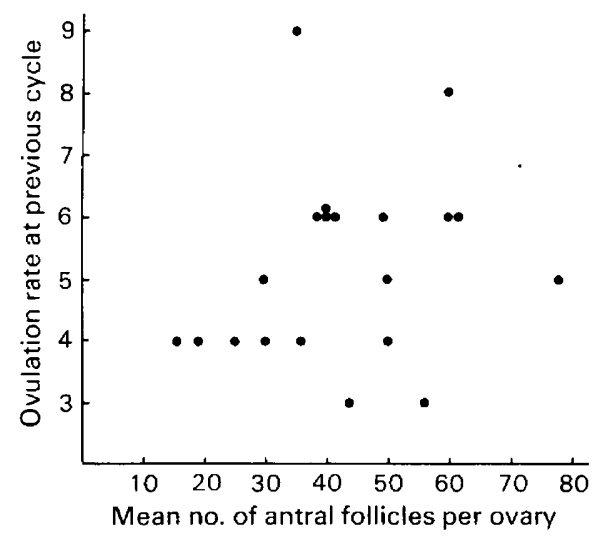

Text-fig. 5. Relationship between the ovulation rate at the previous cycle and the mean number of antral follicles in Booroola ewes.

Table 4. Numerical features (mean \pm s.d.) of the different crops of preovulatory follicles defined by ink labelling at successive times of the follicular phase

\begin{tabular}{|c|c|c|c|c|c|}
\hline & \multicolumn{2}{|c|}{ No. of follicles labelled at Day 13} & \multirow{2}{*}{$\begin{array}{l}\text { No. of follicles not } \\
\text { labelled at Day } 13 \\
\text { being labelled } \\
\text { at Day } 15\end{array}$} & \multirow{2}{*}{$\begin{array}{l}\text { No. of follicles } \\
\text { labelled at Day } 15 \\
\text { and growing or } \\
\text { steady between } \\
\text { Days } 15 \text { and } 17\end{array}$} & \multirow{2}{*}{$\begin{array}{l}\text { No. of follicles } \\
\text { not labelled at } \\
\text { Day } 15 \text { but growing } \\
\text { between Days } 15 \\
\text { and } 17 \text { to ovulate }\end{array}$} \\
\hline & $\begin{array}{l}\text { Growing between } \\
\text { Days } 13 \text { and } 15\end{array}$ & $\begin{array}{c}\text { Regressing between } \\
\text { Days } 13 \text { and } 15\end{array}$ & & & \\
\hline \multicolumn{6}{|l|}{ Control } \\
\hline Merinos & $2.9 \pm 1.3 \dagger$ & $3.1 \pm 1.3+$ & $2 \cdot 0 \pm 1 \cdot 1 \ddagger$ & $1.2 \pm 0.4 \ddagger$ & $0 \ddagger$ \\
\hline Booroola & $2.9 \pm 1.6 \dagger$ & $3.0 \pm 1.7 \dagger$ & $2.7 \pm 1.3 \ddagger$ & $3 \cdot 3 \pm 1 \cdot 2 \ddagger^{*}$ & $1 \cdot 3 \pm 0.5 \ddagger^{*}$ \\
\hline
\end{tabular}

† Data from the ewes of Groups II and III (12 ewes per strain).

$\ddagger$ Data from the ewes of Groups III (6 ewes per strain).

${ }^{*} P<0.01$ compared with value for control Merino.

Table 5. Histological features (mean \pm s.d.) of the population of recruitable follicles in Booroola and control Merino ewes

\begin{tabular}{|c|c|c|c|c|c|c|}
\hline & \multicolumn{2}{|c|}{ Day 13} & \multicolumn{2}{|c|}{ Day 15} & \multicolumn{2}{|c|}{ Day 17} \\
\hline & Booroola & Merino & Booroola & Merino & Booroola & Merino \\
\hline $\begin{array}{l}\text { Total no. } \\
\text { of recruitable } \\
\text { follicles }\end{array}$ & $12 \pm 2 \cdot 5$ & $12 \cdot 1 \pm 1 \cdot 4$ & $9 \pm 1.7$ & $11 \cdot 6 \pm 1 \cdot 9$ & $11 \pm 1 \cdot 8$ & $8 \cdot 5 \pm 1.4$ \\
\hline $\begin{array}{l}\% \text { of normal } \\
\text { follicles among } \\
\text { the recruitable }\end{array}$ & $61 \cdot 0 \pm 11 \cdot 2^{*}$ & $41 \pm 7 \cdot 3$ & $65 \cdot 5 \pm 8 \cdot 1^{*}$ & $48 \cdot 6 \pm 6 \cdot 7$ & $66.8 \pm 9 \cdot 6^{*}$ & $32 \cdot 6 \pm 8.9$ \\
\hline $\begin{array}{l}\text { Mitotic index of the } \\
5 \text { largest healthy } \\
\text { recruitable follicles }\end{array}$ & $0.64 \pm 0.11$ & $0.81 \pm 0.14$ & $0.33 \pm 0.07^{* *}$ & $0.85 \pm 0.17$ & $0.14 \pm 0.03$ & $0.41 \pm 0.09$ \\
\hline
\end{tabular}

Compared with value for control Merino: ${ }^{*} P<0.05 ;{ }^{* *} P<0.01$.

Histological features of the population of recruitable follicles (Exp. I)

Whatever the stage of the cycle, the total numbers (normal plus atretic) of recruitable follicles were similar in the two strains (Table 5). The proportion of normal follicles, however, was significantly higher in Booroola than in control Merino ewes at Days 13, 15 and 17 (Table 5). The mean 
mitotic index of the recruitable follicles (estimated for the 5 largest non-atretic ones) was unaffected by strain at Days 13 and 17 , but at Day 15 it was significantly higher in Merino ewes $(P<0 \cdot 01)$ (Table 5).

Characteristics of the preovulatory follicles (Exp. I)

In ewes of Group III, the repeated laparotomies made it possible to observe the origin of the preovulatory follicles. In the 6 control Merinos, all the putative preovulatory follicles were labelled at Day 13, but in the Booroola ewes the origin of these preovulatory follicles was diverse both between and within animals (Table 6).

Table 6. Origin of the preovulatory follicles in the 6 Booroola ewes ovariectomized just before ovulation (Group III)

\begin{tabular}{lcccccc}
\hline & \multicolumn{7}{c}{ Ewe no. } \\
\cline { 2 - 7 } & 7287 & 7021 & 7265 & 7038 & 7383 & 7077 \\
\hline Labelled at Days 13 and 15 & 0 & 3 & 1 & 3 & 0 & 4 \\
Not labelled at Day 13, & 4 & 1 & 1 & 0 & 2 & 2 \\
$\quad$ labelled at Day 15 & 1 & 2 & 1 & 0 & 2 & 1 \\
\hline Unlabelled at Days 13 and 15 & 1 & &
\end{tabular}

The number of granulosa cells per preovulatory follicle was lower in Booroola than in Merino ewes (Text-fig. 6) $\left(1.09 \pm 0.46 \times 10^{6}\right.$ compared with $\left.2.78 \pm 0.57 \times 10^{6} ; P<0.01\right)$. In the Booroola strain, there was a significant negative correlation $(r=-0.85 ; P<0.05)$ between the number of preovulatory follicles and the number of cells they contained. Pycnotic bodies were extremely rare in preovulatory follicles of both strains when the cumulus area was excluded from observation: only one follicle out of 34 had a pycnotic index exceeding $0.1 \%$. However, pycnosis was common amongst the cumulus cells once they had dissociated.

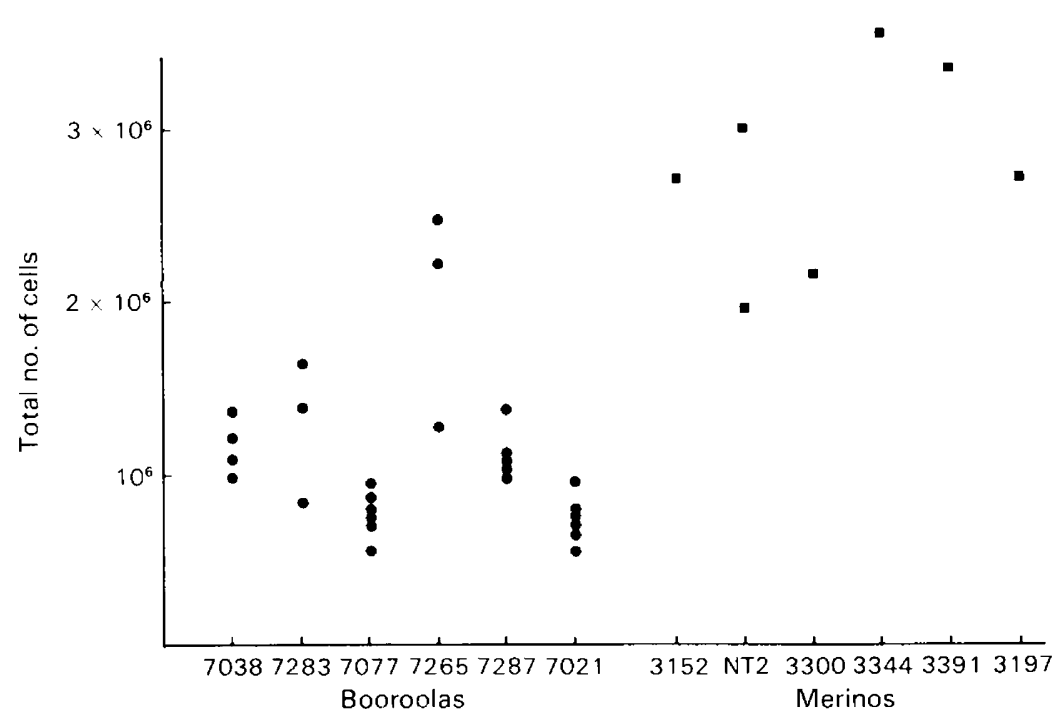

Text-fig. 6. Numbers of granulosa cells per preovulatory follicle of 6 Booroola and 6 control Merino ewes. 


\section{Effect of ageing on follicular populations (Exp. II)}

The number of primordial follicles differed significantly $(P<0.05)$ between strains and between ages with no interactions evident. The Booroola ewes had fewer primordial follicles than did control Merino ewes at both ages and the 2-year-old ewes had more follicles than did the 8-yearold ewes (Table 7). The mean 'loss' of primordial follicles between 2 and 8 years of age was similar in both strains (13 185 in Booroolas, 16103 in controls) and represents a mean loss of 6.0 and 7.4 follicles per day respectively, or 2000-2500 follicles per year. On a proportion basis at 8 years of age, Booroola ewes had 'lost' $84 \%$ of the follicles they had as 2 -year-old ewes and the control Merino ewes had 'lost' $60 \%$ of follicles. However, due to the high within-strain variability, there was no significant difference between strains in the number of preantral or antral follicles (Table 7). Furthermore, whatever the strain, ageing had no effect on the population of preantral and antral follicles (Table 7).

Table 7. Follicular populations (mean and range) of young and aged Merino and Booroola ewes

\begin{tabular}{ccccc}
\hline & & & \multicolumn{2}{c}{ Growing follicles } \\
\cline { 4 - 5 } Strain & $\begin{array}{c}\text { Age } \\
\text { (years) }\end{array}$ & Primordial follicles & Preantral & Antral \\
\hline Booroola & 2 & $15718(4692-32902)$ & $112(65-140)$ & $72(41-132)$ \\
& 8 & $2374(2100-2802)$ & $112(65-158)$ & $84(57-112)$ \\
Merino & 2 & $27018(19237-33416)$ & $79(35-139)$ & $41(38-47)$ \\
& 8 & $10915(5366-16182)$ & $59(42-76)$ & $52(42-65)$ \\
\hline
\end{tabular}

\section{Discussion}

The first feature of this study is that Booroola ewes which had a mean ovulation rate of $5 \cdot 2$ had similar numbers of antral follicles and a higher extent of atresia in this antral population than did the control Merino ewes which had a mean ovulation rate of $1 \cdot 2$. This observation, together with the lack of correlation between the ovulation rate at the previous cycle and the numbers of antral follicles, strongly suggests that the high ovulation rate of the Booroolas is not achieved by having more non-atretic follicles available. These results are in contrast to the result of a previous study on another prolific breed, the Romanov, in which it was shown that the Romanov had twice the number of growing follicles found in the control breed, the Ile-de-France, and the same extent of atresia in the antral population (Cahill et al., 1979). It is therefore likely that every prolific breed has developed its own device to generate a high ovulation rate. Data on follicular populations of Finn and D'Man ewes are awaited with interest to confirm this. While the data on the population of growing follicles in Booroola and Romanov ewes differ, our conclusions on the higher antral follicular population of the twin-ovulating control Merinos compared to those with single ovulations are in good agreement with the study of single and twin-ovulating Ile-de-France ewes (Cahill et al., 1979). Furthermore, this study supports earlier claims of a negative correlation between the number of primordial follicles and the mean ovulation rate of different genetic lines (sheep: Land, 1970; Cahill et al., 1979; rat: Land, de Reviers, Thompson \& Mauléon, 1974). However, it is not known whether this is genetic in origin or a consequence of a higher number of fetuses (Tassell, Kennedy, Bindon \& Piper, 1983) or fetal ovaries (Cahill \& Chamley, 1982) developing during pregnancy.

The fact that ageing results in both strains in a progressive decrease in the number of primordial follicles but with unaltered numbers of preantral and antral follicles confirms the findings of Erickson (1966) for the cow. Extrapolation of the annual loss of primordial follicles from the ovary shows that Booroola and control Merino ewes are depleted of their follicle store at a mean age of 9 and 13 years respectively. However, the observation of a 2-year-old Booroola with very few 
primordial follicles is puzzling, although similar cases have been described in mares (Driancourt, Paris, Roux, Mariana \& Palmer, 1982b). These animals could be abnormal or manage their small stock of primordial follicles for their life time.

The rate of exit from the primordial pool was found in this study to be $2 \cdot 1$ and 1.3 follicles per day in Booroola and control Merino ewes respectively. These values fit well with the estimates of Turnbull et al. (1977) and Cahill \& Mauléon (1980) who showed that 3-4 or 1.5-2 follicles began to grow each day. However, the observed decrease in the number of primordial follicles between the ages of 2 and 8 years suggests that 6-7 follicles leave the primordial pool per day. The difference between the number disappearing and the number starting to grow might be linked to atresia of primordial follicles. Such a phenomenon has never been documented, possibly because there are no adequate criteria for atresia of primordial follicles and because such atresia is probably very rapid (Peters \& Levy, 1964). Comparison of the number of follicles entering the preantral phase and the antral phase ( $2 \cdot 1$ and $1 \cdot 1$ in Booroola, 1.3 and $1 \cdot 1$ in control Merino) strongly suggests that atresia also occurs in preantral follicles. The greater degree of preantral atresia in Booroola ewes is intriguing although a similar occurrence has been found in rats selected for litter size compared to control rats (Spearow, 1980).

Oocyte defects are probably responsible for this atresia since pycnosis is never observed in such follicles. Because differences in ovarian structure at birth between Booroola and control Merino ewes have been reported (Tassell et al., 1983), it is likely that these two strains differ in the timing of some events of oogenesis which results in differences in the quality of the germ cells.

The reasons for the different ovulation rates between the two strains became evident when preovulatory enlargement was followed by ink labelling at the end of the cycle. Two processes can be considered to lead to the development of preovulatory follicles (Di Zerega \& Hodgen, 1981; Driancourt \& Cahill, 1984). Recruitment establishes a group of follicles capable of ovulating, and then there is selection from amongst these follicles of only one or a few that complete their preovulatory enlargement. These processes differed between the two strains studied (Text-fig. 7). In control Merino ewes, recruitment of follicles $\geqslant 2 \mathrm{~mm}$ occurs between Days 13 and 15 and selection of the preovulatory follicle has also occurred by Day 15 . Thereafter no new follicle grows to $>2 \mathrm{~mm}$ in diameter and preovulatory size is $6-8 \mathrm{~mm}$. In Booroolas, a first crop of follicles $\geqslant 1.5 \mathrm{~mm}$ is recruited between Days 13 and 15. By Day 15, follicles of this crop have reached the preovulatory size (3-4 mm), but recruitment continues between Days 15 and 17 . This prolonged recruitment, together with a low intensity of selection and the ability of the follicles generated early to wait for ovulation, gives rise to the high ovulation rate of the Booroola ewes. Histological data support well this pattern established through the ink-labelling observations. During the follicular phase, the lower incidence of atresia in the population of recruitable follicles in Booroola ewes can explain why more of them grow. Finally, the lower mean mitotic index of the recruitable follicles at Day 15 in Booroolas also supports the idea that some follicles are fully grown in this strain at Day 15.

Two mechanisms probably operate in Booroolas to generate this pattern of development of preovulatory follicles. Extended recruitment could be linked to the high FSH levels which have been found in Booroolas during the follicular phase (Bindon et al., 1984) because it is known that, to be recruited, follicles need to be primed by FSH before being adequately sensitive to LH pulses (for review see Driancourt, Gibson \& Cahill, 1983). However, the fact that this FSH-induced extended recruitment is not the only mechanism operating has been demonstrated (Cummins, 1983): depression of FSH in Booroolas to levels similar to those of Merinos by injections of follicular fluid resulted only in a marginal reduction of ovulation rate. It is therefore likely that the low incidence of selection through atresia also contributes significantly to the high ovulation rate of Booroolas. Proteins secreted by the large follicle are likely candidates for the control of selection (for review see Driancourt et al., 1985). As it has been shown in women that the concentrations of inhibin and selection protein in the dominant follicle are correlated (Di Zerega et al., 1984) and that the inhibin content of Booroola ovaries is about one third of that of control ovaries (Cummins, O'Shea, Bindon, Lee \& Findlay, 1983), an exciting hypothesis to explain this low incidence of selection would be a reduced synthesis of the protein(s) controlling selectionaded from Bioscientifica.com at 04/26/2023 05:14:26AM 


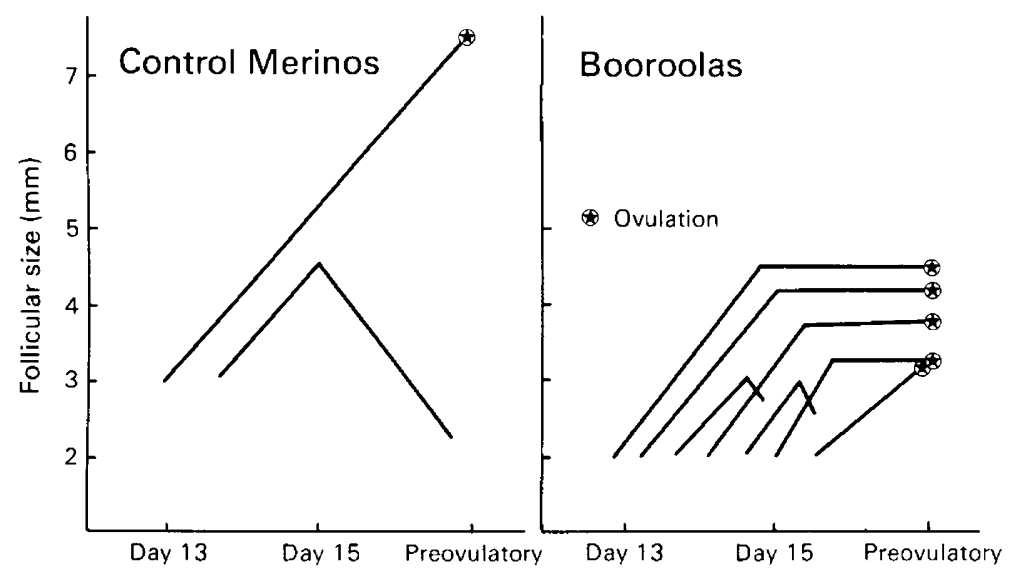

Text-fig. 7. Schematic pattern of preovulatory enlargement throughout the follicular phase in Booroola and control Merino ewes.

Another component of the high ovulation rate of Booroola ewes is the ability of fully grown follicles to wait for up to 2 days for the LH peak. That waiting ability is, however, not surprising, since it has been observed in rodents treated with barbiturates (Uilenbroek, Woutersen \& Van der Schoot, 1980) and in mares, $45 \%$ and $20 \%$ of the follicles do not grow in the 2 or 3 days respectively before ovulation (M. A. Driancourt \& E. Palmer unpublished results). Despite the fact that some of the preovulatory follicles have to wait before ovulation, in none of them was there marked pycnosis and there was no evidence of ovulation of early atretic follicles. This contrasts with the findings of Koering, Goodman, Williams \& Hodgen (1982) for the monkey.

The observation that the total number of granulosa cells per preovulatory follicle in Booroola ewes was less than that in Merinos, possibly because of a smaller preovulatory size, agrees with previous reports (Baird et al., 1982; Scaramuzzi \& Radford, 1983). This study extends these results in showing different patterns of granulosa cell multiplication and antrum development in the two strains. In these two strains, similar size does not mean a similar stage of development and/or sensitivity to gonadotrophins. None of these differences has been observed in the prolific Romanov (Cahill et al., 1979). Furthermore, the finding that preovulatory follicles (which, by definition, are non-atretic and have a similar sensitivity to gonadotrophins) present a 2 -fold variation in the number of their granulosa cells casts doubts on the use of cell numbers as a criterion for atresia and shows that follicular sensitivity to the LH peak is not linked to the number of granulosa cells. It is not, however, known if there is a relationship between the number of cells in a follicle and its early (between Days 13 and 15) or late (after Day 15) formation.

Wide flexibility seems to be a major feature of preovulatory enlargement. In breeds of sheep of limited prolificacy, the hormonal needs for preovulatory growth, the size at luteolysis of the follicle due to ovulate and the timing of selection were shown to be highly variable between ewes (Driancourt et al., 1985). In this study, within the Booroola strain, the diversity in the origin of the preovulatory follicles both within and between animals is striking Finally, this flexibility has also been found in the way prolific breeds generate their high ovulation rate. A similar procedure of ink labelling at repeated laparotomies in Romanov has shown that Romanov ewes differ from Booroolas in their pattern of preovulatory enlargement (M. A. Driancourt, unpublished results).

M.A.D. was on study leave from I.N.R.A., Nouzilly, France, We thank the Australian Wool Corporation for support; Dr W. R. Gibson for helpful criticism of the manuscript; Dr I. J. Clarke for supervision of the progesterone assay; Mr P. Weston for assistance with surgery; and Mrs T. A. Loel and T. R. Purdon for help with histology. 


\section{References}

Abercrombie, M. (1946) Estimation of nuclear population from microtome sections. Anat. Rec. 94, 239247.

Baird, D.T., Ralph, M.M., Seamark, R.F., Amato, F. \& Bindon, B.M. (1982) Pre-ovulatory follicular activity and estrogen secretion of high (Booroola) and low fecundity Merino ewes. Proc. Aust. Soc. Reprod. Biol. 14, 83, Abstr.

Bindon, B.M. \& Piper, L.R. (1982) Physiological characteristics of high fecundity sheep and cattle. Proc. 2nd Wld Congr. Sheep and Beef Cattle Breeding, pp. 315332. Eds R. A. Barton \& W. C. Smith. The Dunmore Press Limited, Palmerston North.

Bindon, B.M., Blanc, M.R., Pelletier, J., Terqui, M. \& Thimonier, J. (1979) Periovulatory gonadotrophin and ovarian steroid patterns in sheep of breeds with differing fecundity. J. Reprod. Fert. 55, 15-25.

Bindon, B.M., Piper, L.R. \& Evans, R. (1982) Reproductive biology of the Booroola Merino. In The Booroola Merino, pp. 21-34. Eds L. R. Piper, B. M. Bindon \& R. D. Nethery. CSIRO, Armidale.

Bindon, B.M., Piper, L.R., Cummins, L.J., O'Shea, T., Hillard, M.A., Findlay, J.K. \& Robertson, D.M. (1984) Reproductive endocrinology of prolific sheep: studies of the Booroola Merino. In Genetics of Reproduction in Sheep, pp. 217-236. Eds R. B. Land \& D. W. Robinson. Butterworths, London.

Cahill, L.P. \& Chamley, W.A. (1982) An influence of the number of ovaries on the population of primordial follicles in the sheep. Proc. Aust. Soc. Reprod. Biol. 14, 77, Abstr.

Cahill, L.P. \& Mauléon, P. (1980) Influence of season, cycle and breed on follicular growth rates in sheep. $J$. Reprod. Fert. 58, 321-328.

Cahill, L.P., Mariana, J.C. \& Mauléon, P. (1979) Total follicular populations in ewes of high and low ovulation rates. J. Reprod. Fert. 55, 27-36.

Cahill, L.P., Saumande, J., Ravault, J.P., Blanc, M., Thimonier, J., Mariana, J.C. \& Mauléon, P. (1981) Hormonal and follicular relationships in ewes of high and low ovulation rates. $J$. Reprod. Fert. 62, 141150.

Cummins, L.J. (1983) Physiological basis of the control of ovulation rate in sheep. Ph.D. thesis, University of New England, Armidale, Australia.

Cummins, L.J., O'Shea, T., Bindon, B.M., Lee, V.W.K. \& Findlay, J.K. (1983) Ovarian inhibin content and sensitivity to inhibin in Booroola and control strain Merino ewes. J. Reprod. Fert. 67, 1-7.

Davis, G.H., Montgomery, G.W., Allison, A.J. \& Kelly, R.W. (1982) Segregation of a major gene influencing fecundity in progeny of Booroola sheep. N.Z.J. agric. Res. 25, 525-529.

Di Zerega, G.S. \& Hodgen, G.D. (1981) Folliculogenesis in the primate ovarian cycle. Endocr. Rev. 2, 27-49.

Di Zerega, G.S., Campeau, J.D., Nakamura, R.N., Ujita, E.L., Lobo, R. \& Marrs, R.P. (1984) Activity of a human follicular fluid protein(s) in spontaneous and induced ovarian cycles. J. clin. Endocr. Metab. 57, $838-846$.

Driancourt, M.A. \& Cahill, L.P. (1984) Preovulatory follicular events in sheep. $J$. Reprod. Fert. 71, 205211 .
Driancourt, M.A. \& Mariana, J.C. (1982) Short and long term effects of $\mathrm{X}$ irradiation on ovarian follicular population in the ewe. Reprod. Nutr. Develop. 22, 813-823.

Driancourt, M.A., Mariana, J.C. \& Palmer, E. (1982a) Effect of the stage of the oestrous cycle on the follicular population in pony mares. Reprod. Nutr. Develop. 22, 803-812.

Driancourt, M.A., Paris, A., Roux, C., Mariana, J.C. \& Palmer, E. (1982b) Ovarian follicular populations in pony and saddle type mares. Reprod. Nutr. Develop. 22, 1035-1047.

Driancourt, M.A., Gibson, W.R. \& Cahill, L.P. (1985) Follicular dynamics throughout the oestrous cycle in sheep: a review. Reprod. Nutr. Develop. 24 (in press).

Dufour, J.J., Whitmore, H.L., Ginther, O.J. \& Casida, L.E. (1972) Identification of the ovulating follicle by its size on different days of the estrous cycle in heifers. J. Anim. Sci. 34, 85-87.

Erickson, B.H. (1966) Development and senescence of the post natal bovine ovary. J. Anim. Sci. 23, 800805.

Gougeon, A. (1981) Cinétique de la croissance et de l'involution des follicules ovariens pendant le cycle menstruel chez la femme. D.Sc. thesis, University of Paris VI.

Gougeon, A. \& Lefèvre, B. (1983) Evolution of the diameters of the largest healthy and atretic follicles during the human menstrual cycle. J. Reprod. Fert. 69, 497-502.

Hoffman, J.G. (1949) Theory of the mitotic index and its application to tissue growth measurement. Bull. mathem. Biophys. 11, 139-143.

Hossain, M.I., Lee, C.S., Clarke, I.J. \& O'Shea, T.D. (1979) Ovarian and luteal blood flow and peripheral plasma progesterone levels in cyclic guinea-pigs. $J$. Reprod. Fert. 57, 167-174.

Koering, M.J., Goodman, A.L., Williams, R.F. \& Hodgen, G.D. (1982) Granulosa cell pyknosis in the dominant follicle of monkeys. Fert. Steril. 37, 837-844.

Lahlou-Kassi, A., Schams, D. \& Glatzel, P. (1984) Plasma gonadotrophin concentration during the oestrous cycle and after ovariectomy in two breeds of sheep with low and high fecundity. J. Reprod. Fert. 70, 165173.

Land, R.B. (1970) Number of oocytes present at birth in the ovaries of pure and Finnish Landrace cross Blackface and Welsh sheep. J. Reprod. Fert. 21, 517521.

Land, R.B. \& Falconer, D.S. (1969) Genetic studies of ovulation rate in the mouse. Genet. Res. 13, 25-46.

Land, R.B., de Reviers, M.M., Thompson, R. \& Mauléon, P. (1974) Quantitative physiological studies of genetic variation in the ovarian activity of the rat. $J$. Reprod. Fert. 38, 29-39.

Lindsay, D.R., Knight, T.W., Smith, J.F. \& Oldham, C.M. (1975) Studies in ovine fertility in agricultural regions of Western Australia: ovulation rate, fertility and lambing performance. Aust. J. agric. Res. 26, 189198.

McKenzie, F.F. \& Terrill, C.E. (1937) Oestrus, ovulation and related phenomena in the ewe. Res. Bull. Mo. Agric. Exp. Stn, No. 264. 
Nilsson, L., Wikland, M. \& Hamberger, L. (1982) Recruitment of an ovulatory follicle in the human following follicle-ectomy and luteectomy. Fert. Steril. 37, 30-34.

Pedersen, T. (1970) Follicle kinetics in the ovary of the cyclic mouse. Acta endocr., Copenh. 64, 304-323.

Peters, H. \& Levy, E. (1964) Effect of irradiation in infancy on the mouse ovary. A quantitative study of cocyte sensitivity. J. Reprod. Fert. 7, 37-45.

Scaramuzzi, R.J. \& Radford, H.M. (1983) Factors regulating ovulation rate in the ewe. J. Reprod. Fert. $69,353-367$.

Smeaton, T.C. \& Robertson, H.A. (1971) Studies on the growth and atresia of Graafian follicles in the ovary of the sheep. J. Reprod. Fert. 25, 243-252.

Sokal, R.R. \& Rohlf, F.J. (1969) Biometry. In The Principles and Practice of Statistics in Biological Research. W.F. Freeman, San Francisco.

Spearow, J.L. (1980) The physiological basis of genetic differences in the ovulation rate of mice. Ph.D. thesis, University of California, Davis.
Tassell, R.J., Kennedy, J.P., Bindon, B.M. \& Piper, L.R. (1983) Ovarian follicles of new born Merino lambs from genetic lines which differ in fecundity. Aust. $J$. biol. Sci. 36, 351-355.

Turnbull, K.E., Braden, A.W.H. \& Mattner, P.E. (1977) The pattern of follicular growth and atresia in the ovine ovary. Aust. J. biol. Sci. 30, 229-241.

Uilenbroek, J.T., Woutersen, P.J.A. \& Van der Schoot, P. (1980) Atresia of preovulatory follicles: gonadotropin binding and steroidogenic activity. Biol. Reprod. 23, 219-228.

Webb, R. \& England, B. G. (1982) Identification of the ovulatory follicle in the ewe: associated changes in follicle size, thecal and granulosa cell luteinizing hormone receptors, antral fluid steroids and circulating hormones during the preovulatory period. Endocrinology 110, 873-881.

Wheeler, A.G. \& Land, R.B. (1977) Seasonal variations in oestrus and ovarian activity of Finnish Landrace, Tasmanian Merino and Scottish Blackface ewes. Anim. Prod. 24, 363-376.

Received 19 March 1984 